\title{
The Environmental Impact of Plastic Waste Incineration
}

\author{
Ágnes NAGY, ${ }^{1}$ Rajmund KUTI ${ }^{2}$
}

\begin{abstract}
According to environmental and safety-conscious behaviour in the $21^{\text {th }}$ century, it is necessary to strive to reduce all those activities that cause environmental damage in every aspect of life. More emphasis should be placed on recycling, waste-handling and environmental-friendly solutions, due to the increased amount of waste caused by the penetration of plastics. Plastic manufacture is a constantly growing industry - especially the production of packaging - so the amount of plastic waste generated is also growing steadily. Only a part of the accumulated waste is recycled, another part is destroyed and the remaining amount will continue to pollute the environment. One form of destruction may be energy recovery or incineration. Destruction is a form of energy recovery or incineration which is subject to strict legal requirements in addition to other possible activities. It could pose a serious burden on the human and natural environment if the process is not properly controlled and monitored. This article writes of the situation that seemingly a growing amount of plastic waste is used in residential combustion appliances, of which adverse environmental and health effects the majority of citizens are not aware, so these will be shown in particular. In this article, we examine the environmental and health effects and harm caused by the burning of plastics in detail. We write this study with the purpose of drawing people's attention to the importance of reducing the quantities of plastic waste and thus the environmental impact they cause as well as the human and environmental risks of incineration.
\end{abstract}

Keywords: environmental safety, environmental damage, plastics, plastic waste, recycling, incineration

\section{Introduction}

Since 1950 we have witnessed the rise of plastics. Plastic products produced from crude oil derivatives - due to continuous technological progress - can be prepared with relatively low manufacturing costs and possess excellent usability characteristics. It is no surprise that global production has increased exponentially. [1] Hungary is also experiencing the expansion of plastics, which involves the formation of steadily growing plastic waste. [2] Nowadays, the management, recycling and disposal of plastic waste is a major issue. These developments pose a serious burden on environmental elements, accordingly, it is essential to examine the

1 Ph.D. student, National University of Public Service, Doctoral School of Military Engineering; e-mail: agnes. nagy.keki@gmail.com

2 Ph.D. (Military Technology), associate professor, Széchenyi István University, Faculty of Mechanical Engineering, Informatics and Electrical Engineering; e-mail: kuti.rajmund@sze.hu 
effects of plastic products and waste on human health and the environment at a deeper level. The scope of this article does not examine the entire process of waste management, therefore, after a general presentation, the energy recovery, the risks of incineration and their adverse effects are analysed.

\section{Features of Plastics, Waste Management}

Plastics are organic compounds consisting of giant molecules which are mostly produced from synthetic oil derivatives. According to user needs, their quality (such as flexibility, impact, fire resistance and special colours, etc.) depends on the various additives allocated into the raw material. In terms of its type, plastic can be thermoplastics or thermosetting polymers. According to Central Statistics Office (CSO) data, in Hungary the population produces approximately 300 thousand tons of plastic waste annually. Most of the plastic waste is thermoplastic packaging, therefore this type of waste is examined in detail. As the majority of plastic does not biodegrade in nature, the most important task is to reduce waste emissions, create responsible management of resulting waste and recycling. [3] [4] The following figure shows the hierarchy of waste management:

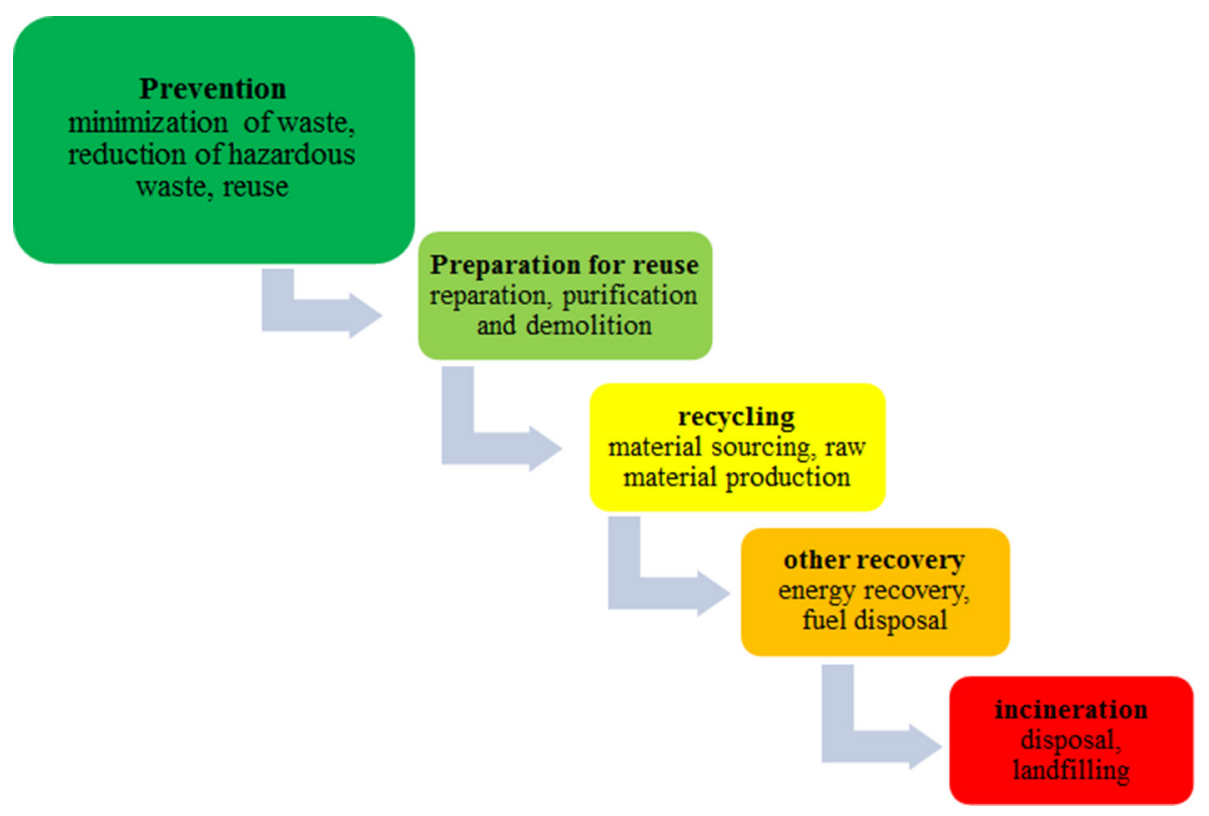

Figure 1. The hierarchy of waste management.

(Compilation of data by the authors based on source [5].)

The colours in the figure are consistent with the environmental influences, which means that energy recovery and incineration can be found at the bottom of the hierarchy, therefore they are not considered to be the most advantageous solutions. 


\section{Risks of Plastic Waste Incineration and Its Adverse Effects}

The incineration of waste as a fuel generates heat energy in cement factories and power plants which is utilized in technological equipment. The resulting heat is used for operating systems, heating and generating power. The disadvantage of combustion of plastics is the air pollution caused by the noxious fumes released into the atmospheres. In Hungary, this activity is regulated by the 29/2014. (XI. 28.) Regulation of the Ministry of Agriculture on waste incineration, technical requirements and operating conditions for the incineration technology and emission limit values. The incineration of waste as a fuel is possible, therefore, subject to licensing only in accordance with legal requirements and technology incineration plants with flue gas filtration equipment along with the continuous monitoring of the combustion gases emitted. The following diagram shows the built-in filtration systems technology.

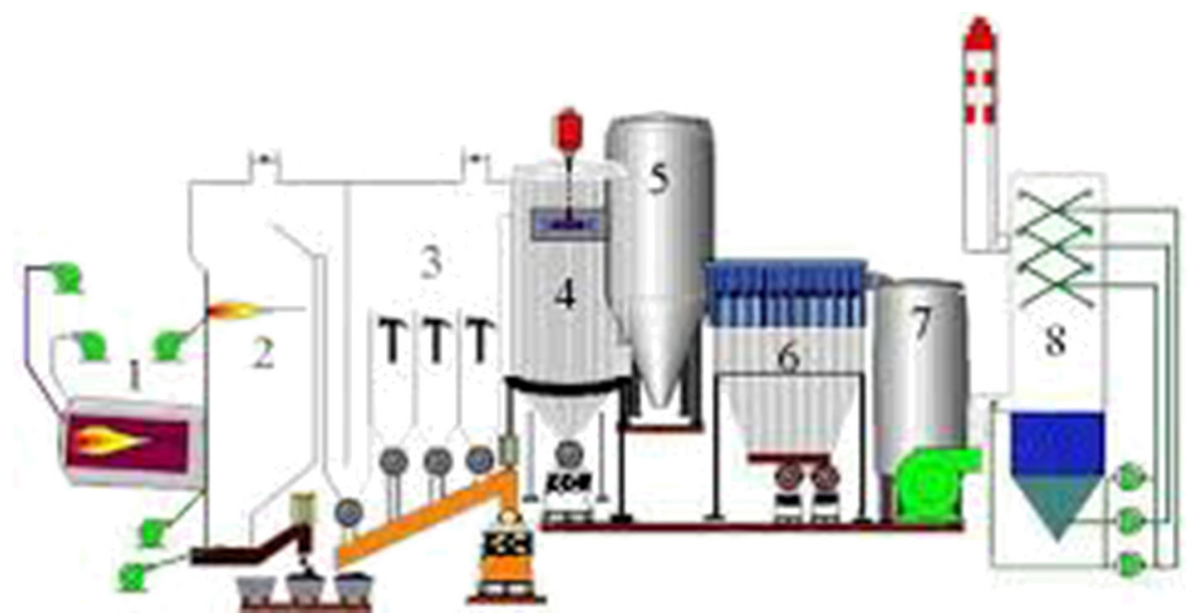

Figure 2. The flow chart of the Incinerator in Sarpi Dorog Environmental Ltd. [6]
Explanation:
1. Rotary Kiln
2. Post-combustion chamber
3. Heat recovery boiler
4. Absorber
5. Calcium hydroxide dust and active carbon reactor
6. Dust bag isolator
7. Catalytic dioxin decontaminator
8. Washing Tower

According to the above-mentioned regulation, plastic waste can only be incinerated in licensed plastic waste incineration plants, all other forms of burning plastic waste are banned. Mostly plastic waste is generated by common households. The introduction of advanced selective waste collection systems has allowed the separation of different materials and types of waste. An important task is to emphasize the benefits of the separation of plastics, so they 
become re-usable and less polluting to our environment. Unfortunately, in Hungary, due to the economic crisis, more and more families are having trouble purchasing fuel for the winter, so the household waste is incinerated, and the harmful effects are not taken into account. During incineration, plastics cause permanent damage to the combustion heater in the flue systems and the resulting combustion products pose a serious threat to both humans and the environment.

The burning of plastics is a complex chemical process. Depending on their structure, plastics can be micro-molecular or macro-molecular compounds. During plastic combustion, different phases take place, such as warming, degradation, flashover, combustion - all which are present at the same time. Low-molecular compounds can be vaporized directly in the air, and depending on their variety, are able to form a combustible mixture, or oxidize in solid form. Macro-molecular plastics have to decompose into small molecule compounds to initiate the combustion process. Burning is accompanied by the formation of chark, coking extent depends on the conditions of combustion. Two zones are formed during the combustion of most plastic. The first zone is the gas evolution (pyrolysis zone), the second zone is the chark zone (between the surface and the pyrolysis zone). [7] The chark zone consists of porous solid residues. Gases generated during the decomposition of the plastic composite products are extremely dangerous.

The most common household plastics are:

- Polyethylene (PE),

- Polyethylene terephthalate (PET),

- Polypropylene (PP),

- Polyamide (PA),

- Poly (vinyl chloride) (PVC),

- Polyurethane (PU).

The combustion characteristics of these plastics are shown below:

Table 1. Combustion characteristics of plastics used in households.

(Details of the authors' compilation based on source [7].)

\begin{tabular}{|l|l|l|}
\hline Name of substance & $\begin{array}{l}\text { Ignition temperature } \\
\left({ }^{\circ} \mathbf{C}\right)\end{array}$ & $\begin{array}{l}\text { Heat of combustion } \\
(\mathbf{M J} / \mathbf{k g})\end{array}$ \\
\hline Polyethylene (PE) & 350 & 46.3 \\
\hline Polyethylene terephthalate (PET) & 500 & 22.7 \\
\hline Polystyrene (PS) & 470 & 41.6 \\
\hline Polypropylene (PP) & 410 & 46.6 \\
\hline Polyamide (PA) & 500 & 31.4 \\
\hline Poly (vinyl chloride) (PVC) & 760 & 19.26 \\
\hline
\end{tabular}

The combustion of plastics presented in Table 1 causes several chemical compounds which mean a serious risk to health and the environmental elements, among which, especially, the incineration of PVC poses the greatest threats, therefore that type of plastic is analysed in detail in this process. The use of poly (vinyl chloride) is highly restricted or banned in many countries of the European Union. However, in Hungary PVC is widely used in the form of 
plumbing and sewage pipes, as the insulation material for electricity cables, floor coverings, furniture coverings and other household items as well.

The compounds generated by the incineration of PVC and its harmful health effects are presented in the following table:

Table 2. Generated compounds and their harmful effects during incineration of PVC.

(Compilation of data by the authors based on source [8].)

\begin{tabular}{|c|c|}
\hline Name of compound & Health effects \\
\hline Acetaldehyde & It damages the nervous system, causing lesions. \\
\hline Acetone & Irritates the eyes, the respiratory tract. \\
\hline Benzaldehyde & Irritates the eyes, skin, respiratory system, limits brain function. \\
\hline Benzole & $\begin{array}{l}\text { Carcinogenic, adversely effects the bone marrow, the liver, the } \\
\text { immune system. }\end{array}$ \\
\hline Formaldehyde & $\begin{array}{l}\text { Serious eye damage, carcinogenic, may cause pulmonary oede- } \\
\text { ma. }\end{array}$ \\
\hline Phosgene & $\begin{array}{l}\text { Gas used in the WWI. Corrosive to the eyes, skin and respiratory } \\
\text { organs. }\end{array}$ \\
\hline $\begin{array}{l}\text { Polychlorinated } \\
\text { dibenzo-dioxin }\end{array}$ & $\begin{array}{l}\text { Carcinogenic, irritates the skin, eyes and respiratory system. It } \\
\text { damages the circulatory, digestive and nervous system, liver, } \\
\text { bone marrow. }\end{array}$ \\
\hline $\begin{array}{l}\text { Polychlorinated } \\
\text { dibenzofuran }\end{array}$ & Irritates the eyes and the respiratory system, causes asthma. \\
\hline Hydrochloric acid & Corrosive to the eyes, the skin and the respiratory tract. \\
\hline Salicyl-aldehyde & $\begin{array}{l}\text { Irritates the eyes, the skin and the respiratory tract. It can also } \\
\text { affect the central nervous system. }\end{array}$ \\
\hline Toluene & Irritates the eyes and the respiratory tract, can cause depression. \\
\hline Xylene & $\begin{array}{l}\text { Irritates the eyes. It can also affect the central nervous system, } \\
\text { reduces the level of consciousness and impairs learning ability. }\end{array}$ \\
\hline Propylene & $\begin{array}{l}\text { Damages the central nervous system by lowering of conscious- } \\
\text { ness. }\end{array}$ \\
\hline Vinyl chloride & $\begin{array}{l}\text { Carcinogenic, irritating to eyes, skin and respiratory system. } \\
\text { Effect on the central nervous system, liver, spleen, blood-forming } \\
\text { organs. }\end{array}$ \\
\hline
\end{tabular}

During the incineration of PVC, up to 2 milligrams per gram of phosgene is generated, which is one of the most dangerous gases, and a serious risk to health. Phosgene $\left(\mathrm{COCl}_{2}\right)$ is an organic compound, colourless, its odour is reminiscent of musty hay, an asphyxiant gas it is a strong poison. It was used as a chemical weapon during World War I. [9] It hydrolyses easily and is freely soluble in non-polar solvents. [10] This also reacts with the condensing vapour during combustion, whereby hydrogen chloride is formed, which is also a toxic compound. The following equation presents this chemical reaction:

$\mathrm{COCl}_{2}+\mathrm{H}_{2} \mathrm{O} \rightarrow \mathrm{CO}_{2}+2 \mathrm{HCl}$ 
The adverse health effects of carbon monoxide gas $(\mathrm{CO})$ and carbon dioxide $\left(\mathrm{CO}_{2}\right)$ generated during the combustion process are well known. In terms of quantities, we can say that every five grams of burned PVC derivatives pollute a cubic meter of air to such an extent that it will surely damage our health. The burning process of mixed waste also produces other toxic compounds, which are fastened to one another and exert their harmful environmental impact. A further problem is that fuel used in household appliances are not designed for burning plastics and other waste, therefore the burning of waste in plants and in flue gas can cause damage. One of the main conditions of the combustion process is the presence of oxygen. The oxygen required for combustion is included. To burn one kg of firewood depending on the variety, $12-16 \mathrm{~m}^{3}$ of air is needed and to burn waste a much larger quantity is necessary. [11] Since the right amount of air cannot be provided, the lack of air results in an inadequate combustion and the flue may result in large amounts of flue gas deposits. The right amount of air cannot be provided, the resulting lack of air causes inadequate combustion which redounds the flue gas to sediment in flue gas deposits. Evacuation of the fumes during combustion is the task of the flue outlets, commonly called chimneys. In order to achieve sufficient heating efficiency, chimneys should be scaled for the heating system. It is also important to assure air supply for combustion. The combustion equipment and chimney system are designed to burn defined fuels. The deviation from the prescribed is always a risk because they may not develop the flue gas exhaust, and drafts of fresh air needed. The burning of domestic waste involves large amounts of flue gas formation, part of which is deposited in the chimney wall and because of the absence of built-in filtering equipment, the other parts enter the environment. The soot formation in the chimney occurs during strenuous plastic waste, burning rubber derivatives. The incineration of mixed waste causes a significant amount of smoke. The smoke flowing through the chimney cools down continuously. Due to the decrease in temperature, water vapour condenses on the chimney wall from the smoke. The plastic compound for smoke derivatives found in the precipitating liquid is acidic. This acidic fluid, on one hand, damages the chimneys internal plaster - this primarily can be said in the case of masonry chimneys - secondly, it is also a good adhesive surface for the solid particles in the exhaust smoke, including black carbon and also a tar inner layer is formed. Due to the constantly sticking flue combustion products the inside of the chimney narrows, therefore the temperature of the exhaust fumes increases. Due to this temperature increase, the internal temperature of the chimney also rises. After reaching the ignition temperature of the flue combustion products deposited in the chimney they ignite and a chimney fire occurs. The internal temperature can reach $1,000{ }^{\circ} \mathrm{C}$ while burning. [12] We have already mentioned the adverse effects of toxic gases arising from the combustion of plastics above, it should also be mentioned that the soil and the aquatic environment suffer from the effects of combustion products. While the combustion of solid combustion products of plastics, ashes, soot and various powders are formed, which settle on the ground objects such as plants or soil, they may appear in the aquatic environment. Rainfall causes blurred toxic substances entering the soil, exerting further polluting effects which allows these substances to become incorporated into the food chain. Some of the contaminants chemically react with water and resulting compounds alter the $\mathrm{pH}$ and thereby change the functioning of aquatic ecosystems. Non-soluble compounds added to the food chain exert their harmful effects. 


\section{Summary}

Hungary is also experiencing an increase in the amount of generated plastic waste. In accordance with the tightening of environmental standards, the priority these days is to manage plastic waste recycling or disposing where possible. In our country, a significant part of plastic waste is used as energy recovery or incinerated, which processes are not the most advantageous solutions environmentally. Unfortunately, despite the legal prohibition of residential combustion where plastic is also burnt, the majority of citizens are not aware of the dangers of environmental and health impacts. In this article, we have examined the environmental and health effects, harmful and toxic materials in detail generated during incineration, highlighted the example of burning PVC. With this script, we wish to draw attention to the reduction in the volume of plastic waste and the importance of protecting our environment.

\section{References}

[1] HALÁSZ L: Hőre lágyuló műanyagok extrudálása. Műanyag és Gumi, 484 (2011), 129-135.

[2] BELINA K., HALÁSZ L., VORSTER. O. C., JUHÁSZ P.: Alfa olefin homo és kopolimerek kristályosodási tulajdonságai. Múanyag és Gumi, 438 (2006), 347-356.

[3] FÖLDI L., HALÁSZ L.: Környezetbiztonság. Budapest: Complex Kiadó Kft., 2009.

[4] PADÁNYI J., FÖLDI L.: Environmental responsibilities of the military soldiers have to be “Greener Berets”. Economics and Management, 2 (2014), 48-55.

[5] A 2055/2013 Korm. határozattal elfogadott Országos Hulladékgazdálkodási Terv 20142020.

[6] Technológiai folyamatábra. Sarpi Dorog Környezetvédelmi Kft. www.sarpi.hu/ technologiai_folyamatabra (Downloaded: 154 2016)

[7] KOMPOLTHY T., SZALAY L.: Tüz- és robbanásvédelem. Budapest: Műszaki Könyvkiadó, 1990.

[8] PÁL K.: Mũanyaghulladékok égetése. Budapest: Műszaki Könyvkiadó, 1990.

[9] GRÓSZ Z.: Az ABV Védelem alapjai. Budapest: Zrínyi Miklós Nemeztvédelmi Egyetem, 2003. (Tankönyv)

[10] HALÁSZ L., NAGY K.: Mérgező anyagok kémiája. Budapest: Zrínyi Miklós Nemeztvédelmi Egyetem, 2001. (Egyetemi jegyzet)

[11] KOVÁCS I.: Égés és tûzoltás. Budapest: Cedit Kft., 1997.

[12] KUTI R., ZÓLYOMI G.: Vegyes tüzelésű fütőberendezések használatának kockázatai. Védelem Online Túz-és Katasztrófavédelmi Szakkönyvtár, 2016. www.vedelem.hu/ letoltes/anyagok/741-vegyes-tuzelesu-futoberendezesek-hasznalatanak-kockazatai.pdf (Downloaded: 204 2016) 